\title{
Assessing the levels of HIV-related knowledge and attitudes toward HIV-infected patients among undergraduate dental students: a cross-sectional study
}

This article was published in the following Dove Medical Press journal: HIVIAIDS - Research and Palliative Care

\author{
Reham Khaled Abou El \\ Fadl' \\ Ahmed Abdelmoety ${ }^{2}$ \\ Zeinab Farahat ${ }^{3}$ \\ Mohamed Ali Hussein ${ }^{4}$ \\ 'Pediatric Dentistry and Dental \\ Public Health Department, Faculty of \\ Dentistry, Ain Shams University, Cairo, \\ Egypt; ${ }^{2}$ Center for Development \\ Services, Cairo, Egypt; ${ }^{3}$ World Food \\ Programme Regional Bureau Cairo, \\ Cairo, Egypt; ${ }^{4}$ Faculty of Commerce, \\ South Valley University, Qena, Egypt
}

Correspondence: Reham Khaled Abou El Fadl

Pediatric Dentistry and Dental Public Health Department, Faculty of Dentistry, Ain Shams University, 5 El Tahawy Street, Roxy, Heliopolis II34I, Cairo, Egypt Tel +20 I00 544 I I7।

Email reham.k.abouelfadı@gmail.com
Purpose: Worldwide, in the last decade, the numbers of new HIV infections and AIDS-related deaths have drastically decreased. Despite that, around 18 million infected individuals receive antiretroviral therapy and thus tend to live longer. This cross-sectional study was conducted to assess the level of HIV-related knowledge among undergraduate dental students at Ain Shams University (ASU) in Cairo, Egypt and to determine their attitudes toward treating HIV-positive patients.

Methods: The study sample included 247 undergraduate dental students of third, fourth, and fifth academic years at the Faculty of Dentistry, ASU who were randomly selected to participate in this survey. Data were collected using a self-administrated anonymous questionnaire. Chi square and ANOVA tests were used to measure differences in the level of knowledge and attitudes among students of the 3 years. Multiple linear regression analysis was performed with $95 \%$ confidence interval.

Results: Within the students' population, around $94 \%$ incorrectly considered dentists to be at high risk of acquiring HIV infection and $47 \%$ believed that saliva is a vehicle for its transmission. Moreover, the majority of students were unaware of the association between HIV and common oral manifestations such as oral candida, Kaposi sarcoma, and leukoplakia. Although $69 \%$ of the students were willing to deliver oral care to people living with HIV (PLHIV), only $33 \%$ perceived themselves knowledgeable enough to do so.

Conclusion: Dental students were not adequately prepared to recognize and manage HIVpositive individuals. Thus, better education and training are required to raise their levels of HIV-related knowledge and enhance their capabilities to treat PLHIV.

Keywords: HIV, dental students, behavior, willingness to treat, Egypt

\section{Introduction}

Globally, HIV and AIDS epidemics pose huge public health challenges. According to the global summary of the AIDS epidemic of WHO, in 2016, the number of people living with HIV (PLHIV) was 36.7 million of which 2.1 million were children aged 15 years and under. ${ }^{1}$ In Egypt, while $<0.02 \%$ of the total population lives with HIV, the incidence of new infections is exponentially growing among key populations who are at high risk of exposure including drug users, sex workers, and men who have sex with men. ${ }^{2}$

It is well known that HIV infection negatively affects oral health wherein $40 \%-70 \%$ of HIV-positive individuals develop oral complications such as Kaposi sarcoma, oral 
candidiasis, and leukoplakia during disease progression. ${ }^{3,4}$ Due to dry mouth symptoms and lack of cleansing action of saliva, these patients also suffer from multiple carious lesions and periodontal problems. ${ }^{5,6}$ It is not uncommon that in individuals with unknown positive HIV status dentists are the first to detect oral manifestations signaling infection. ${ }^{7,8}$ Whereas dental practitioners are morally duty bound to deliver comprehensive oral care of high quality to PLHIV and denial of treatment based on HIV status is unacceptable, ${ }^{9}$ it has been reported that unmet dental needs are highly prevalent among this vulnerable group of patients. ${ }^{10-12}$

Worldwide, stigma and discrimination (S\&D) associated with the HIV epidemic are still persistent and both have exceedingly devaluated PLHIV through exclusion and marginalization. ${ }^{13,14}$ Accordingly, HIV-positive individuals face challenges in disclosing their health status while seeking medical care, as health care providers (HCPs) tend to deny them access to services inside various health facilities, including dental settings. Engaging in this kind of behavior could be attributed to the lack of HIV-related knowledge, especially regarding modes of transmission, among HCPs causing subsequent fear of acquiring the infection while treating PLHIV. Furthermore, the fear of being stigmatized by their families and communities and concerns about losing their HIV-free patients are primary factors that contribute to providers being reluctant to treat HIV-positive individuals. ${ }^{15,16}$ Based on the findings of a cross-sectional study in Egypt, out of 529 men and women living with HIV who were interviewed on their experiences with HIV-related S\&D, 40\% asserted that on attending health care facilities, including dental settings, they do not inform HCPs about their HIV status whereas $>50 \%$ stated that they were denied service upon revealing they had the infection. ${ }^{17}$

As the right to receive the highest standards of health care among PLHIV has been globally reiterated, ${ }^{18,19}$ it is crucial to address the determinants of HIV-related S\&D in health facilities including oral health settings to ensure equitable access of those patients to all health services. The attitude of dental students toward delivering oral care for PLHIV has been widely studied in many countries such as India, the United States, the United Arab Emirates, Kuwait, Nigeria, Iran, and Sudan. ${ }^{20-26}$

To date and to the best of the authors' knowledge, no studies were conducted in any dental school in Egypt on students' knowledge and skills to manage HIV-positive individuals and their willingness to treat them. In this respect, this study was conducted to assess the ability of undergraduate dental students to recognize HIV-associated oral manifestations, their knowledge of the modes of transmission of this infection, their perceptions regarding dentists' obligations toward PLHIV as well as their willingness to treat those patients.

\section{Materials and methods Study design, setting, and research participants}

A descriptive cross-sectional study was conducted among the undergraduate students attending the third, fourth, and fifth study years at the Faculty of Dentistry, Ain Shams University (ASU) located in Cairo, the capital of Egypt. ASU is a governmental educational institution operating under the supervision of the Egyptian Ministry of Higher Education. It is the third oldest university in Egypt having been established in 1950 and the Faculty of Dentistry is one of 15 faculties under the umbrella of the University. Within this public educational institution, preventive and curative oral health services are delivered in the outpatient clinics of the University premises by undergraduate and postgraduate dental students under the supervision of staff members. The undergraduate dental program offered by the Faculty of Dentistry at ASU lasts for 5 years. The program also includes another year of internship where students exclusively focus on working alongside qualified dentists to develop their clinical skills through exposure to patients in all the dental disciplines.

\section{Inclusion/exclusion criteria}

Only students enrolled in the third, fourth, and fifth study years represented the targeted population of this study, as according to the program specifications, students start getting introduced to basic dental sciences in year 3 and then in the last 2 years (4 and 5) they study clinical dental sciences and start treating patients in a clinical setting. Members from the students union who participated in the process of data collection were excluded from the study sample.

\section{Questionnaire}

A self-administered questionnaire partly adapted from comparable studies previously conducted to capture the level of HIV-related knowledge among dental students in other countries and measure their attitudes toward treating PLHIV $^{20,25,26}$ was made available in English language. The questionnaire consisted of three main sections including 30 closed-ended questions. The first section included questions on dental students' demographic details including gender, age, and place of origin as well as year of study and educational background of parents. Students were also asked to indicate whether their main sources of information on HIV 
and AIDS included lectures, Internet, radio and TV, friends and relatives, or reading material.

In the second section, in order to assess the dental students' knowledge on the characteristics of HIV infection and AIDS, the questionnaire included four statements on the progression of HIV infection up to the stage of AIDS among all PLHIV, HIV survival period outside human tissues, the clinical incubation period, and the average time interval between contracting HIV and producing antibodies. The level of students' knowledge regarding the modes of transmission of HIV was also determined using five questions on the risk of transmission through unprotected heterosexual and homosexual intercourse or body fluids such as blood, semen, or breast milk or after needle stick injury or occupational exposure to saliva as well as spread by touching, kissing, coughing, sharing food or drink, or through sharing public toilets and swimming pools. Two statements on dentists' risk of contracting HIV infection during practice and infection control measures required to prevent transmission in dental settings were also included.

Moreover, the knowledge section consisted of four questions pertaining to the prevalence of HIV in Egypt and availability of treatment for it, whether or not HIV medications have cidal effects on the virus, and whether or not infected individuals not receiving medical treatment pose higher risk for HIV transmission. All questions assessing the participants' HIV-related knowledge had simple check off answers "yes," "no," or "I do not know." In one part of this section of the questionnaire, the students had to decide which of 15 different oral manifestations could be associated with HIV infection. All of the 15 manifestations listed were correct answers and therefore marking each one would score one. In the last section, the attitudes of dental students toward treating HIV-positive individuals and their perceptions regarding the obligations of dental practitioners to provide oral care to those patients were addressed. The participants were asked to rate eight statements on a five-point Likert scale (strongly agree, agree, neutral, disagree, and strongly disagree).

\section{Ethical considerations}

Permission to conduct the study was obtained from the principals at the Faculty and ethical approval was granted by the Research Ethical Committee of the Faculty of Dentistry, ASU in February 2016. The purpose of the study was explained to all the randomly selected students who were assured that all responses were anonymous. Written informed consent was obtained from all respondents prior to participation.

\section{Recruitment}

In the Faculty of Dentistry at ASU, undergraduate students in all academic years are divided into small-sized groups for attending practical sessions. A list of all students in each academic year was accessed through the Faculty's administrative office; the total number of students in years 3,4 , and 5 was 300,321 , and 274 , respectively. The following formula was used to determine the sample size, $n$ :

$$
\mathrm{n}=\frac{\mathrm{P}(1-\mathrm{P}) \mathrm{Z}^{2}}{\mathrm{E}^{2}}
$$

where

$\mathrm{n}=$ sample size;

$\mathrm{Z}=$ the value on the $\mathrm{Z}$ table at $95 \%$ confidence level $=1.96$;

$E=$ sampling error at $5.12 \%$;

$\mathrm{P}=$ maximum variability of the population at $50 \%$, ie, $(0.5)$.

Three hundred and sixty seven dental students were randomly selected from the third, fourth, and fifth study years. Simple random sampling of participants was performed using a digital online software (https://www.randomizer.org/) such that the range of serial numbers of students in every small group was entered and the software presented a set of random numbers. Approximately 10-12 students per group in each year $(40 \%$ of the population) were sampled.

\section{Data collection}

Data collection was performed inside the premises of the Faculty of Dentistry, ASU from mid-March toward the end of April 2016. Members from dental students' union at the Faculty disseminated the surveys on a voluntary basis to the randomly selected students while attending their weekly practical sessions. After explaining the purpose of the study, all students who agreed to participate were given 20 minutes to read and sign the informed consent form and fill the questionnaire during the same session.

\section{Statistical analysis}

Data were entered using Epi Info ${ }^{\mathrm{TM}}$ version 7.2 (Centers for Disease Control and Prevention/Division of Health Informatics and Surveillance, Atlanta, GA, USA) and later exported to be tabulated using Microsoft Excel worksheet. The data set was imported into spreadsheets, and statistical analysis was then performed using SPSS software version 16.0 (SPSS Inc, Chicago, IL, USA). Descriptive statistics, including means, SDs, frequencies, and percentages were calculated 
for variables as appropriate. Chi square test and ANOVA were used to measure differences in the level of knowledge and attitude between third, fourth, and fifth year students when applicable. Multiple linear regression analysis was performed for modeling the main determinants of the knowledge scores as well as modeling the relationship between the knowledge scores and the attitude score with $95 \%$ confidence interval.

An index for the level of HIV-related knowledge was created using the sum of all items of knowledge and internal consistency among all these items was found to be high (Cronbach's alpha =0.69). Similarly, an index for the attitudes of the students toward treating infected individuals was created using the sum of all items of attitudes and the internal consistency was low (Cronbach's alpha $=0.34$ )

\section{Results}

\section{Background characteristics of participants}

Out of 367 dental students of both genders who were randomly selected from the third, fourth, and fifth study years, 247 filled the questionnaire with a response rate of $67.3 \%$ and $>64 \%$ of the respondents were female students. As reported by $67 \%$ of participants, academic lectures were the most frequently used source of HIV- and AIDS-related information; only $37 \%$ denoted that they received information from the Internet.

\section{HIV-related knowledge of dental students Knowledge related to HIVIAIDS characteristics and its status in Egypt}

In our study, only $30.5 \%$ knew that medical treatment for $\mathrm{HIV}$ is available in Egypt and $33.1 \%$ of participants correctly responded to the statement "HIV can survive up to 1 hour outside human tissues" with highly significant differences between the responses of students from the 3 years $(P<0.01)$ (Table 1$)$.

\section{Knowledge of HIV modes of transmission}

As shown in Table 2, $>84 \%$ of the respondents gave the correct answer to the statement "Infection control measures to prevent hepatitis $\mathrm{C}$ infection can also prevent the transmission of HIV in the dental setting" and the knowledge of students in year 4 was significantly the highest $(P<0.01)$.

With respect to the dental students' knowledge about HIV transmission in dental clinics, only $35 \%$ correctly agreed that "The risk for HIV infection after needle stick injury or after exposure of non-intact skin to HIV contaminated blood is $<0.5 \%$." On the other hand $71 \%$ of students in year 4 correctly disagreed with the statement "Occupational exposure to saliva in the dental setting can readily transmit HIV to the dentist;" compared to only $44 \%$ in both years 3 and 5 , indicating a highly significant difference $(P<0.01)$ in the level of knowledge between respondents of the 3 academic years.

\section{Knowledge of oral manifestations associated with HIV infection}

The difference in the level of dental students' knowledge regarding some HIV-related oral manifestations was highly significant $(P<0.01)$, such that those in the third year were the least knowledgeable that oral conditions such as Kaposi sarcoma (20\%), non-Hodgkin's lymphoma (8.8\%), hairy leukoplakia (17.3\%), thrombocytopenic purpura (9.9\%), and human papilloma virus (14.8\%) could signal HIV infection (Table 3 ).

\section{Dental students' attitudes toward management of HIV-infected individuals}

Using Chi square test, a highly significant difference was found between the attitudes of students from the 3 academic years when asked about the moral and legal obligation of dentists to treat PLHIV, their willingness to perform mouth-

Table I Knowledge regarding HIV status in Egypt and infection/AIDS disease characteristics

\begin{tabular}{|c|c|c|c|c|c|}
\hline \multirow[t]{2}{*}{ Statement } & \multicolumn{3}{|c|}{ Correct responses $(\%)$ ( $95 \%$ confidence interval) } & \multirow{2}{*}{$\begin{array}{l}\text { Total (\%) } \\
(95 \% \mathrm{Cl})\end{array}$} & \multirow[t]{2}{*}{$P$-value } \\
\hline & Third year & Fourth year & Fifth year & & \\
\hline $\begin{array}{l}\text { Percentage of HIV-infected individuals in Egypt is } \\
\text { above } 1 \% \text { of the total population }\end{array}$ & $16(8,24)$ & $7(1.6,12.4)$ & $15.2(7.3,23.1)$ & $12.6(8.7,16.7)$ & 0.148 \\
\hline $\begin{array}{l}\text { Medical treatment is available in Egypt for HIV- } \\
\text { infected individuals* }\end{array}$ & $47.5(36.6,58.4)$ & $11.9(5.1,18.7)$ & $32.9(22.6,43.2)$ & $30.5(24.8,36.2)$ & $<0.001$ \\
\hline HIV can survive up to I hour outside human tissues* & $17.5(9.2,25.8)$ & $4 I(30.6,5 I .4)$ & $40.5(29.7,51.3)$ & $33.1(27.2,39)$ & 0.001 \\
\hline Every HIV-infected individual develops AIDS & $38.5(28,49.1)$ & $55.4(44.9,66)$ & $49.4(38.4,60.4)$ & $47.9(4 I .7,54.1)$ & 0.094 \\
\hline $\begin{array}{l}\text { The average time interval between contracting HIV } \\
\text { and producing antibodies is } 6-12 \text { weeks** }\end{array}$ & $31.6(2 I .5,4 I .7)$ & $5 \mathrm{II} .8(4 \mathrm{I} .2,62.4)$ & $50.6(39.6,61.6)$ & $44.9(38.7,5 \mathrm{I} . \mathrm{I})$ & 0.016 \\
\hline $\begin{array}{l}\text { For most HIV-infected individuals, clinical incubation } \\
\text { period can extend to } 8 \text { years* }\end{array}$ & $32.5(22.3,42.7)$ & $38.8(28.5,49.1)$ & $6 I(50.3,71.7)$ & $43.8(37.6,50)$ & 0.001 \\
\hline
\end{tabular}

Note: *Significant at level I\%; **significant at level $5 \%$. 
Table 2 Knowledge of HIV modes of transmission

\begin{tabular}{|c|c|c|c|c|c|}
\hline \multirow[t]{2}{*}{ Statement } & \multicolumn{3}{|c|}{ Correct responses $(\mathrm{Cl})$} & \multirow[t]{2}{*}{ Total (\%) (Cl) } & \multirow[t]{2}{*}{$P$-value } \\
\hline & Third year (\%) & Fourth year (\%) & Fifth year (\%) & & \\
\hline $\begin{array}{l}\text { Dentists are among the high-risk groups to contract } \\
\text { HIV infection }\end{array}$ & $8.8(2.6,14.9)$ & I.2 (-I.I, 3.5) & $8.8(2.5,15)$ & $6.1(3.1,9.1)$ & 0.065 \\
\hline $\begin{array}{l}\text { Infection control measures to prevent hepatitis C } \\
\text { infection can also prevent the transmission of HIV in } \\
\text { the dental setting* }\end{array}$ & $70.4(60.5,80.3)$ & $100(100,100)$ & $82.3(73.9,90.7)$ & $84.3(79.8,88.8)$ & $<0.001$ \\
\hline $\begin{array}{l}\text { AIDS is a contagious disease; it can be transmitted } \\
\text { through sharing public toilets and swimming pools* }\end{array}$ & $48.1(37.5,59)$ & $81.2(72.9,89.5)$ & $55.7(44.8,66.6)$ & $62(55.9,68.1)$ & $<0.001$ \\
\hline $\begin{array}{l}\text { HIV can spread by touching, kissing, coughing, sharing } \\
\text { food or drink* }\end{array}$ & $50.6(39.7,61.5)$ & $79.5(7 I, 88)$ & $53.8(42.9,64.7)$ & $61.5(55.4,67.6)$ & $<0.001$ \\
\hline $\begin{array}{l}\text { HIV can be transmitted from the infected mother to } \\
\text { her newborn infant during breastfeeding }\end{array}$ & $42.5(31.7,53.3)$ & $4 I(30.6,5 I .4)$ & $29.1(19.1,39.1)$ & $37.6(31.6,34.6)$ & 0.162 \\
\hline $\begin{array}{l}\text { Body fluids that contain high concentrations of HIV and } \\
\text { have been linked to transmission of the virus are blood, } \\
\text { semen, vaginal secretions, breast milk** }\end{array}$ & $70(60,80)$ & $86.7(79.5,93.9)$ & $73 . I(63.4,82.8)$ & $76.8(71.5,82.1)$ & 0.026 \\
\hline $\begin{array}{l}\text { The risk for HIV infection after needle stick injury or } \\
\text { after exposure of non-intact skin to HIV contaminated } \\
\text { blood is }<0.5 \% *\end{array}$ & $20(I I .3,28.7)$ & $34(23,44)$ & $52.6(4 I .7,63.5)$ & $35.4(29.4,41.4)$ & $<0.001$ \\
\hline $\begin{array}{l}\text { Occupational exposure to saliva in the dental setting } \\
\text { can readily transmit HIV to the dentist* }\end{array}$ & $44.4(33.6,55.2)$ & $70.6(61,80)$ & $44.3(33.4,55.2)$ & $53.5(47.3,59.7)$ & $<0.001$ \\
\hline
\end{tabular}

Note: *Significant at level $1 \%$; **significant at level $5 \%$.

Table 3 Dental students' knowledge of HIV-associated oral manifestations

\begin{tabular}{|c|c|c|c|c|c|}
\hline \multirow[t]{2}{*}{ Oral manifestation } & \multicolumn{3}{|l|}{ Yes (\%) (95\% Cl) } & \multirow[t]{2}{*}{ Total (\%) (CI) } & \multirow[t]{2}{*}{$P$-value } \\
\hline & Third year (\%) & Fourth year (\%) & Fifth year (\%) & & \\
\hline Oral candidiasis & $\begin{array}{l}45.7 \\
(34.9,56.5)\end{array}$ & $\begin{array}{l}62.1 \\
(51.8,72.4)\end{array}$ & $\begin{array}{l}60.8 \\
(50 . I, 7 \mid .5)\end{array}$ & $\begin{array}{l}56.3 \\
(50.1,62.5)\end{array}$ & 0.063 \\
\hline Recurrent aphthous ulcer** & $\begin{array}{l}21 \\
(12.1,29.9)\end{array}$ & $\begin{array}{l}23.3 \\
(14.4,32.2)\end{array}$ & $\begin{array}{l}38 \\
(27.4,48.6)\end{array}$ & $\begin{array}{l}27.2 \\
(21.7,32.7)\end{array}$ & 0.032 \\
\hline Kaposi's sarcoma* & $\begin{array}{l}20 \\
(11.3,28.7)\end{array}$ & $\begin{array}{l}36.8 \\
(26.6,47)\end{array}$ & $\begin{array}{l}54.4 \\
(43.5,65.3)\end{array}$ & $\begin{array}{l}37 \\
(40,43)\end{array}$ & $<0.001$ \\
\hline Necrotizing ulcerative periodontitis & $\begin{array}{l}13.6 \\
(6.1,21.1)\end{array}$ & $\begin{array}{l}19.8 \\
(11.4,28.2)\end{array}$ & $\begin{array}{l}28.8 \\
(18.9,38.7)\end{array}$ & $\begin{array}{l}20.6 \\
(15.6,25.6)\end{array}$ & 0.057 \\
\hline Non-Hodgkin's lymphoma* & $\begin{array}{l}8.8 \\
(2.6,15)\end{array}$ & $\begin{array}{l}25.3 \\
(16.1,34.5)\end{array}$ & $\begin{array}{l}41.8 \\
(31,52.6)\end{array}$ & $\begin{array}{l}25.2 \\
(19.8,30.6)\end{array}$ & $<0.001$ \\
\hline Cytomegalovirus ulcers** & $\begin{array}{l}18.5 \\
(10,27)\end{array}$ & $\begin{array}{l}28.7 \\
(19.1,38.3)\end{array}$ & $\begin{array}{l}37.5 \\
(26.9,48.1)\end{array}$ & $\begin{array}{l}28.2 \\
(22.6,33.8)\end{array}$ & 0.028 \\
\hline Linear gingival erythema** & $\begin{array}{l}8.6 \\
(2.5,14.7)\end{array}$ & $\begin{array}{l}7 \\
(1.6,12.4)\end{array}$ & $\begin{array}{l}20 \\
(11.2,28.8)\end{array}$ & $\begin{array}{l}11.7 \\
(7.7,15.7)\end{array}$ & 0.019 \\
\hline Xerostomia & $\begin{array}{l}44.4 \\
(33.6,55.2)\end{array}$ & $\begin{array}{l}34.5 \\
(24.5,44.5)\end{array}$ & $\begin{array}{l}40.5 \\
(29.7,51.3)\end{array}$ & $\begin{array}{l}39.7 \\
(33.6,45.8)\end{array}$ & 0.412 \\
\hline Oral hairy leukoplakia* & $\begin{array}{l}17.3 \\
(9.1,25.5)\end{array}$ & $\begin{array}{l}51.2 \\
(40.6,61.8)\end{array}$ & $\begin{array}{l}57.5 \\
(46.7,68.3)\end{array}$ & $\begin{array}{l}42.1 \\
(35.9,48.3)\end{array}$ & $<0.001$ \\
\hline Salivary gland enlargement $* *$ & $\begin{array}{l}30.9 \\
(20.8,4 I)\end{array}$ & $\begin{array}{l}16.1 \\
(8.3,23.9)\end{array}$ & $\begin{array}{l}17.5 \\
(9.2,25.8)\end{array}$ & $\begin{array}{l}21.4 \\
(16.3,26.5)\end{array}$ & 0.039 \\
\hline Herpes zoster & $\begin{array}{l}23.8 \\
(14.5,33.1)\end{array}$ & $\begin{array}{l}26.7 \\
(17.3,36.1)\end{array}$ & $\begin{array}{l}35.4 \\
(24.9,45.9)\end{array}$ & $\begin{array}{l}28.6 \\
(22.9,34.2)\end{array}$ & 0.237 \\
\hline Herpes simplex** & $\begin{array}{l}29.6 \\
(19.7,39.5)\end{array}$ & $\begin{array}{l}32.6 \\
(22.7,42.5)\end{array}$ & $\begin{array}{l}47.5 \\
(36.6,58.4)\end{array}$ & $\begin{array}{l}36.4 \\
(30.4,42.4)\end{array}$ & $0.04 I$ \\
\hline Lichen planus & $\begin{array}{l}39.5 \\
(28.9,50.1)\end{array}$ & $\begin{array}{l}36 \\
(25.9,46.1)\end{array}$ & $\begin{array}{l}28.8 \\
(18.9,38.7)\end{array}$ & $\begin{array}{l}34.8 \\
(28.9,40.7)\end{array}$ & 0.343 \\
\hline Immune thrombocytopenic purpura* & $\begin{array}{l}9.9 \\
(3.4,16.4)\end{array}$ & $\begin{array}{l}29.1 \\
(19.5,38.7)\end{array}$ & $\begin{array}{l}22.8 \\
(13.6,32)\end{array}$ & $\begin{array}{l}20.7 \\
(15.6,25.8)\end{array}$ & 0.008 \\
\hline Human papilloma virus lesions* & $\begin{array}{l}14.8 \\
(7.1,22.5)\end{array}$ & $\begin{array}{l}39.1 \\
(28.8,49.4)\end{array}$ & $\begin{array}{l}38.8 \\
(28.1,49.5)\end{array}$ & $\begin{array}{l}31 \\
(25.2,36.8)\end{array}$ & 0.001 \\
\hline
\end{tabular}

Note: *Significant at level $1 \%$; **significant at level $5 \%$. 
to-mouth resuscitation, or deliver emergency dental care to those patients when necessary as well as the obligation of patients to reveal their HIV status to dentists. The students' perceptions of their capabilities to identify HIV-related oral lesions and properly manage infected individuals also varied significantly $(P<0.01)$ (Table 4$)$. On comparing the level of HIV-related knowledge and attitudes toward treating infected individuals between students in the 3 academic years, a highly significant difference could be observed as shown in Table 5 .

As shown in Table 6, three multiple linear regression models were created. First model was used for modeling the main determinants of the knowledge index. The second model demonstrated the relationship between the total knowledge index and the attitude index while the third model determined the relationship between each of the four knowledge components (ie, HIV characteristics, modes of transmission, treatment, and HIV-associated oral manifestation) and the attitude index. Only the year of study had a significant impact on students' knowledge and attitudes.

\section{Discussion}

Within HIV-infected populations, oral health disparities prevail with respect to individuals' perception of their oral health status, their oral care seeking behavior, and the levels of unmet dental needs. ${ }^{27}$ In the current study, the vast majority of undergraduate dental students at ASU depended on academic lectures as the main source of information pertaining to HIV and AIDS. Although the overall level of their knowledge was unacceptable, it improved while advancing through the program. Likewise, in a recent cross-sectional study in four universities in the United Arab Emirates the average total score for HIV-related knowledge of both medical and dental students was 4.3 out of $7(61 \%){ }^{28}$

As revealed in our study, there was a lack of adequate information with respect to HIV modes of transmission; this is in accordance with the findings of two similar studies in which a considerable number of respondents wrongly believed that infection could be acquired through touching HIV-positive patients or sharing public toilets. ${ }^{28,29}$ Moreover, though it has been widely reiterated, $<40 \%$ of the study participants were aware of the fact that an infected mother could readily transmit HIV infection to her infant at any point during breastfeeding. ${ }^{30}$ Similarly, only half of the students from two dental schools in Kuwait and Sri Lanka realized that breast milk is a potential route of HIV transmission to children. $^{23}$

It is worth mentioning that this knowledge gap among our study participants could be attributed to the fact that the undergraduate dental program at ASU does not include any separate course on the management of patients with infectious

Table 5 Comparison of the mean knowledge and attitude scores among dental students of 3 academic years

\begin{tabular}{|l|l|l|}
\hline Year of study & $\begin{array}{l}\text { Knowledge index, } \\
\text { mean } \pm \text { SD }\end{array}$ & $\begin{array}{l}\text { Attitude index, } \\
\text { mean } \pm \text { SD }\end{array}$ \\
\hline Third & $10.37 \pm 4.8$ & $16.05 \pm 3.1$ \\
Fourth & $13.79 \pm 3.8$ & $16.3 \mathrm{I} \pm 2.7$ \\
Fifth & $14.09 \pm 4.3$ & $13.92 \pm 3.4$ \\
Total & $12.7 \mathrm{I} \pm 4.6$ & $15.48 \pm 3.2$ \\
\hline ANOVA & $\mathrm{I} 6.82^{*}(P<0.00 \mathrm{I})$ & $\mathrm{I} 3.57^{*}(P<0.00 \mathrm{I})$ \\
\hline Post hoc & Fifth year, fourth year $>$ & $\begin{array}{l}\text { Fourth year, third } \\
\text { year }>\text { fifth year }\end{array}$ \\
comparisons & third year & \\
\hline
\end{tabular}

Note: *Significant at level I\%.

Table 4 Dental students' attitudes toward PLHIV

\begin{tabular}{|c|c|c|c|}
\hline Attitude statement & $\begin{array}{l}\text { Mean } \pm \\
\text { SD }\end{array}$ & Chi square & $P$-value \\
\hline $\begin{array}{l}\text { Every dentist in Egypt should be legally bound to provide routine dental care to HIV-infected } \\
\text { individuals* }\end{array}$ & $3.32 \pm 0.93$ & 283.19 & $<0.001$ \\
\hline $\begin{array}{l}\text { Right now you perceive yourself capable of detecting HIV-related oral lesions and properly manage } \\
\text { HIV-infected individuals* }\end{array}$ & $1.88 \pm 1.06$ & 151.57 & $<0.001$ \\
\hline $\begin{array}{l}\text { Providing dental care to HIV-infected individuals can discourage others from seeking care in a dental } \\
\text { setting* }\end{array}$ & $1.83 \pm 1.23$ & 49.15 & $<0.001$ \\
\hline $\begin{array}{l}\text { Dentists should be willing to perform mouth-to-mouth resuscitation on an AIDS patient in case of } \\
\text { respiratory arrest* }\end{array}$ & $1.67 \pm 1.21$ & 34.44 & $<0.001$ \\
\hline HIV-infected individuals are obliged to reveal their HIV status to their dentists* & $0.53 \pm 0.93$ & 412.44 & $<0.001$ \\
\hline $\begin{array}{l}\text { Infection control measures for management of HIV-infected individuals could raise the costs for dental } \\
\text { practice?* }\end{array}$ & $1.97 \pm 1.28$ & 49.48 & $<0.001$ \\
\hline Dental health care professionals are morally bound to provide routine dental care to PLHIV* & $3.15 \pm 0.87$ & 225.71 & $<0.001$ \\
\hline In your dental practice, you will deliver emergency dental care to HIVIAIDS patient if the need arises* & $2.91 \pm 0.92$ & 144.40 & $<0.001$ \\
\hline
\end{tabular}

Note: *Significant at level $1 \%$.

Abbreviation: PLHIV, people living with HIV. 
Table 6 Determinants of knowledge score and attitude score

\begin{tabular}{|c|c|c|c|}
\hline \multirow[t]{3}{*}{ Independent variables } & \multicolumn{3}{|l|}{ Dependent variables } \\
\hline & $\begin{array}{l}\text { Model (I) } \\
\text { knowledge }\end{array}$ & $\begin{array}{l}\text { Model (2) } \\
\text { attitudes }\end{array}$ & $\begin{array}{l}\text { Model (3) } \\
\text { attitudes }\end{array}$ \\
\hline & Coefficients $(95 \% \mathrm{Cl})$ & Coefficients $(95 \% \mathrm{Cl})$ & Coefficients $(95 \% \mathrm{Cl})$ \\
\hline Age & $-0.02(-1.1, I .1)$ & $0.27(-0.5 \mathrm{I}, \mathrm{I} .05)$ & $0.26(-0.53,1.04)$ \\
\hline $\begin{array}{l}\text { Year of study } \\
\text { Third year (reference) } \\
\text { Fourth year } \\
\text { Fifth year }\end{array}$ & $\begin{array}{l}3.4 I^{*}(1.75,5.07) \\
4.13^{*}(1.74,6.53)\end{array}$ & $\begin{array}{l}-0.48(-1.7,0.8) \\
-2.95^{*}(-4.7,-1.2)\end{array}$ & $\begin{array}{l}-0.70(-1.98,0.6) \\
-3.01 *(-4.8,-1.2)\end{array}$ \\
\hline $\begin{array}{l}\text { Place of origin } \\
\text { Urban governorates (reference) } \\
\text { Lower Egypt } \\
\text { Upper Egypt } \\
\text { Frontiers region } \\
\text { Not Egyptian }\end{array}$ & $\begin{array}{l}0.17(-1.9,2.2) \\
1.29(-1.4,3.9) \\
-1.98(-10.7,6.7) \\
2.24(-2.6,7.04)\end{array}$ & $\begin{array}{l}0.73(-0.8,2.2) \\
1.14(-0.9,3.2) \\
1.23(-1,3.8) \\
1.90(-1.5,5.3)\end{array}$ & $\begin{array}{l}0.66(-0.8,2.1) \\
1.32(-0.79,3.4) \\
1.37(-1.1,3.9) \\
1.56(-1.9,5)\end{array}$ \\
\hline $\begin{array}{l}\text { Father's education } \\
\text { Illiterate (reference) } \\
\text { Less than high school } \\
\text { High school } \\
\text { Two years academy } \\
\text { University and above }\end{array}$ & $\begin{array}{l}0.51(-4.3,5.3) \\
-0.49(-4.5,3.5) \\
-1.94(-4.6,0.7) \\
-2.32(-9.2,4.1)\end{array}$ & $\begin{array}{l}-4.04(-12.5,4.4) \\
-5.43(-13.5,2.6) \\
-5.51(-13.4,2.4) \\
-4.09(-11.7,3.5)\end{array}$ & $\begin{array}{l}-4.09(-12.5,4.3) \\
-4.96(-13,3.09) \\
-5.09(-13.03,2.8) \\
-3.99(-11.6,3.6)\end{array}$ \\
\hline $\begin{array}{l}\text { Mother's education } \\
\text { Illiterate (reference) } \\
\text { Less than high school } \\
\text { High school } \\
\text { Two years academy } \\
\text { University and above }\end{array}$ & $\begin{array}{l}-4.45(-13.3,4.4) \\
-1.97(-9.4,5.5) \\
-4.98(-12.3,2.4) \\
-2.57(-9.7,4.6)\end{array}$ & $\begin{array}{l}1.68(-2.4,5.8) \\
-0.17(-2.1,1.7) \\
0.76(-1.1,2.6) \\
1.71(-2.5,5.9)\end{array}$ & $\begin{array}{l}1.6 \mathrm{I}(-2.5,5.7) \\
-0.20(-2.1,1.7) \\
0.83(-1.01,2.7) \\
1.85(-2.8,6.1)\end{array}$ \\
\hline $\begin{array}{l}\text { Gender } \\
\text { Female (reference) } \\
\text { Male }\end{array}$ & $0.61(-0.68,1.9)$ & $-0.31(-1.3,0.65)$ & $-0.25(-1.2,0.7 I)$ \\
\hline Knowledge on HIV characteristics & - & - & $0.19(-0.21,0.59)$ \\
\hline Knowledge on modes of HIV transmission & - & - & $0.38(0.04,0.7)$ \\
\hline Knowledge on HIV treatment & - & - & $0.04(-0.5,0.6)$ \\
\hline Knowledge on oral manifestations associated with HIV & - & - & $0.03(-0.13,0.2)$ \\
\hline Knowledge & - & $0.13(0.02,0.23)$ & - \\
\hline Constant & $|3.28|(-9.7,36.2)$ & $13.3(-5,31.5)$ & $\mid 2.8(-5.6,3 \mid .2)$ \\
\hline$R^{2}$ & 0.20 & 0.16 & 0.18 \\
\hline ANOVA & $F=3.34 *$ & $F=2.37 *$ & $F=2.19 *$ \\
\hline
\end{tabular}

Note: *Significant at level $1 \%$.

diseases. However, because in year 4 students start their clinical practice, this year's curriculum included 10 hours of lectures and practical sessions on infection control which provided them with some theoretical and practical knowledge on infectious diseases such as hepatitis C and HIV. This explains why year 4 students were found to be significantly the most knowledgeable about the modes of transmission of these conditions.

Although dental clinics are good settings for identifying HIV-positive individuals based on multiple oral manifestations which appear at the early stages of infection, ${ }^{31}$ it was obvious that unlike Indian dental students,${ }^{20}$ the undergraduate students at ASU were not well trained to identify potential HIV patients and the majority perceived themselves incapable of detecting HIV-related oral lesions.

In the present study, the dental students' poor knowledge regarding this infectious disease could be partly attributed to conservative cultures and the deeply entrenched HIV- and AIDS-related phobia in the Middle East and North Africa region generally. ${ }^{32}$ In the Egyptian society, the sociocultural taboos around discussions related to sexuality, reproductive health, and sexually transmitted diseases might lead to limited 
access to information on HIV not only among lay people but also within HCPs' populations. ${ }^{33-35}$ This has been revealed in one qualitative study conducted in a public hospital in Egypt where the participating physicians and nurses indicated that their fear of getting infected or being stigmatized, their inadequate knowledge about proper infection control measures, and their beliefs that HIV infection is acquired only due to inappropriate sexual behaviors validated their discriminatory attitudes toward those patients. ${ }^{15}$ Furthermore, owing to the very low prevalence of HIV in Egypt, ${ }^{2}$ inclusion of adequate knowledge pertaining to oral manifestations of HIV infection, its modes of transmission, and management of PLHIV in undergraduate dental program curricula might not have been considered an urging priority.

Whereas $85 \%$ of the respondents in our survey had the correct knowledge that adhering to a standard set of infection control measures adequately prevents both hepatitis $\mathrm{C}$ and HIV transmission, $42 \%$ of them compared to $32 \%$ in Crossley's study in South Cheshire in the United Kingdom believed that preventing transmission of HIV infection while treating affected patients would increase the costs of dental treatment. ${ }^{36}$ Owing to this misconception, in the future, dental students might preclude HIV-positive patients from receiving dental treatment in their private practice to avoid any additional financial burdens. Surprisingly, around $90 \%$ of students who participated in our survey rejected the view that $\mathrm{HIV}$-infected individuals should reveal their health status to dentists. A plausible explanation for their response could be that it is generally agreed that in any dental facility strict barrier techniques should be used routinely in consideration that any patient could be potentially infectious. ${ }^{37}$

It is worth mentioning that the dental students who participated in this study were randomly selected and invited to respond to a self-administered anonymous questionnaire to eliminate the possibility of any bias due to any external pressure on the participants. Although the response rate was not low, it is important to highlight that our study addressed a disease that is "culturally sensitive" in conservative communities due to its direct link to sexuality and this might have discouraged some students to participate. One limitation that should be considered is that the findings of our study reflect the knowledge and views of students at one public dental school and thus cannot be generalized to all undergraduate Egyptian dental students considering that generally studied curricula vary from one school to another. Moreover, private schools and those in different geographical contexts within the country might attract students of different socioeconomic backgrounds and cultural beliefs which might impact their responses.

\section{Conclusion}

In conclusion, even though the majority of undergraduate dental students at ASU exhibited some positive attitude toward PLHIV, the overall level of HIV-related knowledge among the students was quite unsatisfactory and the failure of the majority of them to identify oral manifestations commonly associated with HIV is worrisome. Consequently, it is crucial to instill more confidence in dental students in their ability to recognize oral problems of PLHIV and deliver quality oral care to patients whenever required. Hence, the undergraduate dental program curricula need to be redesigned to ensure provision of adequate, consistent, and up-to-date information on HIV to students throughout all years of study.

It is also highly recommended that future dentists should receive training that promotes direct interaction between students and PLHIV to allow them to share their perspectives as patients and thus help combat stigma around them and eliminate any sociocultural barriers that could restrict their access to oral care. This could be done through partnership with civil society organizations and other stakeholders who are dedicated to improving the lives of HIV-infected individuals using different teaching approaches such as role playing, video acting, or innovative case-based group learning exercises. In addition, similar studies need to be conducted in other public and private universities in Egypt to assess and compare the knowledge and attitudes of dental students toward PLHIV.

\section{Acknowledgments}

This study was carried out in collaboration and with support from the Center for Development Services, an Egyptian Private Sector company sponsoring many health-related initiatives in Egypt. The authors of the paper would like to express their sincere gratitude to all the dental students who willingly completed the survey, the volunteers who assisted in data collection, and the principals at the Faculty of Dentistry, Ain Shams University, who facilitated conduction of the survey. The views expressed herein are those of the authors and do not necessarily reflect the views of the World Food Programme.

\section{Author contributions}

All authors contributed toward data analysis, drafting and critically revising the paper, gave final approval of the version to be published, and agree to be accountable for all aspects of the work. RKAEF, AA, and ZF developed the concept for this research. RKAEF and AA designed the survey tool and supervised the process of data collection; ZF conducted the software programing for data management; and MAH carried out the statistical analysis of the study data. RKAEF wrote 
the study protocol and the manuscript; AA participated in writing the initial draft; and $\mathrm{MAH}, \mathrm{AA}$, and $\mathrm{ZF}$ reviewed and edited the final manuscript independently until a consensus was reached about the final version.

\section{Disclosure}

The authors report no conflicts of interest in this work.

\section{References}

1. World Health Organization. Summary of the global HIV epidemic (2016). Available from: http://www.who.int/hiv/data/epi_core_2016. png?ua=1. Accessed March 25, 2019.

2. Family Health International. HIV/AIDS Biological and Behavioral Surveillance Survey. Cairo, Egypt: Family Health International; 2010.

3. Nayak S, Nayak S, das B, das S, Mohapatra N, Bhuyan L. Oral manifestations of human immunodeficiency virus/acquired immunodeficiency syndrome and their correlation to cluster of differentiation lymphocyte count in population of north-east India in highly active antiretroviral therapy era. Contemp Clin Dent. 2016;7(4):539-543.

4. Wiebe CB, Epstein JB. An atlas of HIV-associated oral lesions: a new classification and diagnostic criteria. J Can Dent Assoc. 1997;63(4): 288-289.

5. Nittayananta W, Talungchit S, Jaruratanasirikul S, et al. Effects of longterm use of HAART on oral health status of HIV-infected subjects. $J$ Oral Pathol Med. 2010;39(5):397-406.

6. Lin AL, Johnson DA, Stephan KT, Yeh C-K. Alteration in salivary function in early HIV infection. J Dent Res. 2003;82(9):719-724.

7. Weinert M, Grimes RM, Lynch DP. Oral manifestations of HIV infection. Ann Intern Med. 1996;125(6):485-496.

8. Reznick DA. Oral manifestations of HIV disease. Top HIV Med. 2005;13(5):143-148.

9. American Dental Association. ADA principles of ethics and code of professional conduct - 4: A.1; 2011. Available from: http://www.ada. org/1382.aspx. Accessed January 15, 2017.

10. Mofidi M, Gambrell A. Community-based dental partnerships: improving access to dental care for persons living with HIV/AIDS. $J$ Dental Educ. 2009;73(11):1247-1259.

11. Jeanty Y, Cardenas G, Fox JE, et al. Correlates of unmet dental care need among HIV-positive people since being diagnosed with HIV. Public Health Rep. 2012;127(Suppl 2):17-24.

12. Koyio L, Ranganathan K, Kattappagari KK, Williams DM, Robinson PG. Oral health needs assessment world-wide in relation to HIV. Themes: oral health needs and inequalities, oral health promotion, coordinating research and enhancing dissemination in relation to HIV- a workshop report. Oral Diseases. 2016;22(Suppl. 1): 199-205.

13. UNAIDS. Fact sheet on stigma and discrimination; December 2003. Available from: http://data.unaids.org/publications/Fact-Sheets03/ fs_stigma_discrimination_en.pdf. Accessed January 27, 2017.

14. UNAIDS. Global report; UNAIDS report on the global AIDS epidemic 2013. Available from: http://www.unaids.org/en/resources/ documents/2013/20130923_UNAIDS_Global_Report_2013.Accessed February 12, 2017.

15. Abdelrahman I, Lohiniva AL, Kandeel A, et al. Learning about barriers to care for people living with HIV in Egypt: a qualitative exploratory study. J Int Assoc Provid AIDS Care. 2015; 14(2):141-147.

16. Lohiniva A-L, Kamal W, Benkirane M, et al. HIV stigma toward people living with HIV and health providers associated with their care: qualitative interviews with community members in Egypt. J Assoc Nurses AIDS Care. 2016;27(2):188-198.

17. Joint United Nations Programme on HIV/AIDS (UNAIDS), United Nations Children's Fund (UNICEF). Stigma experienced by people living with HIV in Egypt. A research based on PLHIV Stigma Index methodology. Cairo: Egyptian Society for Population Studies and Reproductive Health (ESPSRH); 2013.
18. United Nations High Commissioner for Human Rights and the Joint United Nations Program on HIV/AIDS (UNAIDS). International guidelines on HIV/AIDS and human rights; October 23, 2006. Available from: http://data.unaids.org/Publications/IRC-pub07/JC1252InternGuidelines_en.pdf. Accessed February 14, 2017.

19. United Nations High Commissioner for Human Rights and World Health Organization (WHO). The right to health; fact sheet no. 31; 2008. Available from: http://www.ohchr.org/Documents/Publications/ Factsheet31.pdf. Accessed February 14, 2017.

20. Oberoi SS, Marya CM, Sharma N, Mohanty V, Marwah M, Oberoi A. Knowledge and attitude of Indian clinical dental students towards the dental treatment of patients with human immunodeficiency virus (HIV)/acquired immune-deficiency syndrome (AIDS). Int Dent J. 2014;64(6):324-332.

21. Hamershock RA, Rajabiun S, Fox JE, et al. Dental students' HIV/ AIDS-related knowledge, attitudes, and intentions: impact of the U.S. health resources and services administration's community-based dental partnership program. J Dent Educ. 2014;78(8):1106-1117.

22. Premadasa G, Sadek M, Ellepola A, Sreedharan J, Muttappallymyalil J. Knowledge of and attitudes towards HIV/AIDS: a survey among dental students in Ajman, UAE. J Investig Clin Dent. 2015;6(2):147-155.

23. Ellepola ANB, Sundaram DB, Jayathilake S, Joseph BK, Sharma PN. Knowledge and attitudes about HIV/AIDS of dental students from Kuwait and Sri Lanka. J Dent Educ. 2011;75(4):574-581.

24. Azodo CC, Ehigiator O, Oboro HO, et al. Nigerian dental students' willingness to treat HIV-positive patients. J Dent Educ. 2010;74(4):446-452.

25. Sadeghi M, Hakimi H. Iranian dental students' knowledge of and attitudes towards HIV/AIDS patients. J Dent Educ. 2009;73(6):740-745.

26. Nasir EF, Åstrøm AN, David J, Ali RW. HIV and AIDS related knowledge, sources of information, and reported need for further education among dental students in Sudan- a cross sectional study. BMC Public Health. 2008;8(1):286.

27. Patton LL, Strauss RP, Mckaig RG, Porter DR, Eron JJ. Perceived oral health status, unmet needs, and barriers to dental care among HIV/AIDS patients in a North Carolina cohort: impacts of race. J Public Health Dent. 2003;63(2):86-91.

28. Haroun D, El Saleh O, Wood L, Mechli R, Al Marzouqi N, Anouti S. Assessing knowledge of, and attitudes to, HIV/AIDS among university students in the United Arab Emirates. PLoS One. 2016;11(2):e0149920.

29. Brailo V, Pelivan I, Škaricić J, Vuletić M, Dulcić N, Cerjan-Letica G. Treating patients with HIV and hepatitis B and C infections: Croatian dental students' knowledge, attitudes, and risk perceptions. J Dent Educ. 2011;75(8):1115-1126.

30. World Health Organization. Updates on HIV and infant feeding; 2016. Available from: http://apps.who.int/iris/bitstream/10665/ 246260/1/9789241549707-eng.pdf?ua=1. Accessed March 14, 2017.

31. Coogan MM, Greenspan J, Challacombe SJ. Oral lesions in infection with human immunodeficiency virus. Bull World Health Organ. 2005;83(9):700-706.

32. Setayesh H, Roudi-Fahimi F, El Feki S, Ashford LS. HIV and AIDS in the Middle East and North Africa. Washington, DC, USA: Population Reference Bureau; June 2014.

33. Ebied EM. Factors Contributing To HIV/AIDS - Related stigma and discrimination attitude in Egypt: suggested stigma reduction. guide for nurses in family health centers. J Educ Pract. 2014;5(24):35-46.

34. Population Council, Egypt. Panel survey of young people in Egypt 2014: generating evidence for policies and programs; June 2015. Available from: http://egypt.unfpa.org/sites/default/files/pub-pdf/6be3baf2-61e34de4-bc9b-221f5180cd18.pdf. Accessed March 14, 2017.

35. Abdel-Tawab N, Oraby D, Saher S, Ismail S. Understanding HIV-related vulnerabilities and stigma among Egyptian youth. Cairo, Egypt: Population Council; 2016.

36. Crossley ML. An investigation of dentists' knowledge, attitudes and practices towards HIV+ and patients with other blood-borne viruses in South Cheshire, UK. Br Dent J. 2004;196(12):749-754.

37. Centers for Disease Control and Prevention. Summary of infection prevention practices in dental settings: basic expectations for safe care. Atlanta, GA: Centers for Disease Control and Prevention, US Department of Health and Human Services; 2016. Available from: https://www.cdc.gov/ oralhealth/infectioncontrol/pdf/safe-care2.pdf. Accessed March 16, 2017. 


\section{Publish your work in this journal}

HIV/AIDS - Research and Palliative Care is an international, peerreviewed open access journal focusing on advances in research in HIV, its clinical progression and management options including antiviral treatment, palliative care and public healthcare policies to control viral spread. The journal is included in PubMed. The manuscript man-

Submit your manuscript here: https://www.dovepress.com/hivaids---research-and-palliative-care-journal 